\title{
Analysis of the Prevailing Weather Conditions Criteria to Evaluate the Adoption of a Future ECA in the Mediterranean Sea
}

\author{
M. Castells, F.X. Martínez de Osés \& J.J. Usabiaga \\ Department of Nautical Sciences and Engineering, Universitat Politecnica de Catalunya (UPC), \\ BarcelonaTech, Spain
}

\begin{abstract}
Appendix III of MARPOL's Annex VI sets out the criteria and procedures for designating an emission control area (ECA).This criteria includes: a clear delineation of the proposed ECA; land and sea areas at risk; emission quantification and impact assessment; prevailing weather conditions; data on marine traffic; and land based measures concurrent with the ECA adoption. This paper analyses one of these parameters: prevailing weather conditions to evaluate the adoption of a future ECA in the Mediterranean Sea. Results will demonstrate how marine emissions will impact the sea and land ecology in the Mediterranean area.
\end{abstract}

\section{INTRODUCTION}

There is a growing voice calling for an ECA in the Mediterranean area, claiming significant damages to the environment, crops and health; produced by emissions from shipping both in Mediterranean Sea coastal countries as well as further in shore. The last ship emissions inventory for the Mediterranean developed by Entec UK limited in 2007 appointed that intra-European movements, i.e. Short Sea Shipping (SSS), contributed in 2005 significantly to emissions in the Mediterranean Sea, as $38 \%$ of the fuel consumed corresponded to intra-European movements (16\% domestic and 22\% between EU countries).

Building on the statistics of "Maritime transport statistics - short sea shipping of goods" published by the Eurostat (Eurostat, 2012), short sea shipping traffic volumes in the Mediterranean are already recovering from the downturn suffered due to the current economic crisis. Containerized and RoRo cargo which in 2010 represented $29.4 \%$ of the total short sea shipping volumes in the Mediterranean are emerging strong, registering highest traffics shares ever.

The International Maritime Organization has adopted the mandatory installation of Automatic Identification System (AIS) requirements. Based on the AIS data analysis and processing, data of traffic around the world and in the Mediterranean can be analyzed (Xiang, 2012).
Figure 1 clearly depict the high vessel density areas around the world and the main traffic lanes connecting the economic centers in Asia, Africa, Europe and the Americas crossing the Atlantic, Pacific and Indian Oceans. As can be seen, the Mediterranean sees lots of ship traffic.

Table 1. Short sea shipping cargo volumes (in percentage) in the Mediterranean, 2006-2010. Source: Own, based in Eurostat

\begin{tabular}{|c|c|c|c|c|c|}
\hline Cargo (\%) & 2006 & 2007 & 2008 & 2009 & 2010 \\
\hline Liquid bulk goods & 51.0 & 50.3 & 49.8 & 49.8 & 48.6 \\
\hline Dry bulk goods & 16.6 & 15.8 & 15.6 & 18.0 & 15.7 \\
\hline Large containers & 16.2 & 16.7 & 17.4 & 18.0 & 18.3 \\
\hline $\begin{array}{l}\text { Ro-Ro (self } \\
\text { propelled units) }\end{array}$ & 5.3 & 5.3 & 6.0 & 4.8 & 7.1 \\
\hline $\begin{array}{l}\text { Ro-Ro (non -self } \\
\text { propelled units) }\end{array}$ & 4.6 & 5.4 & 3.9 & 3.9 & 4.0 \\
\hline Other & 6.4 & 6.4 & 7.3 & 5.5 & 6.3 \\
\hline Total (million tons) & 564 & 584 & 589 & 563 & 570 \\
\hline
\end{tabular}




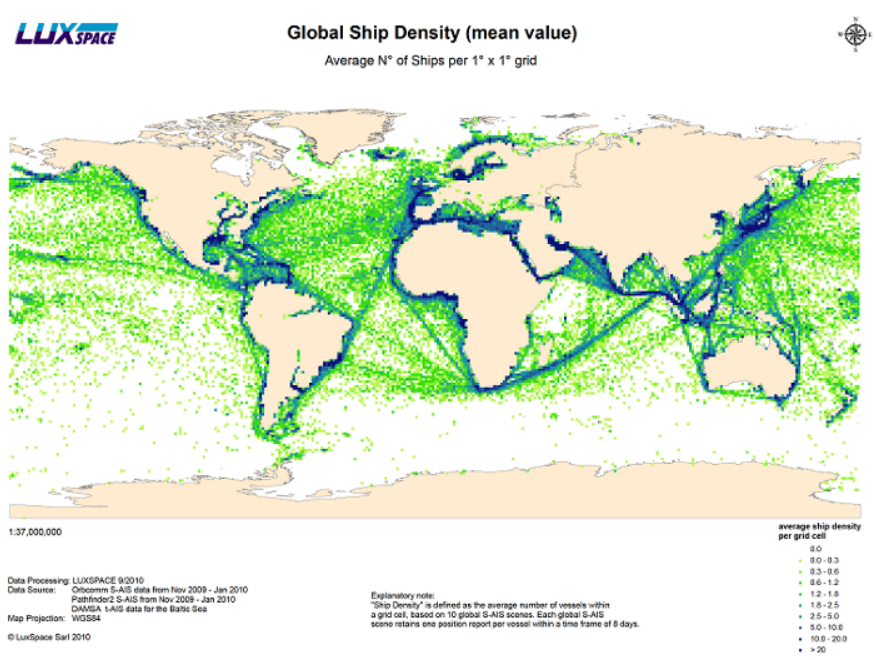

Figure 1. Global ship density map of all class A vessels. Source (Eiden, 2010)

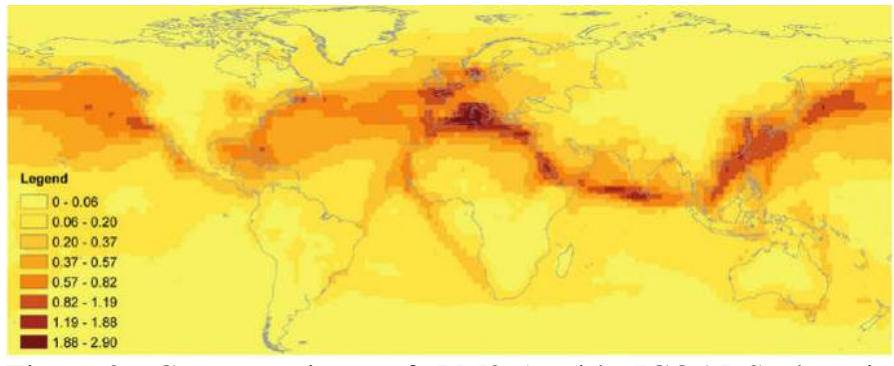

Figure 2. Concentrations of PM2.5 with ICOADS data in micrograms per cubic meter. Source: Winebrake, et al. 2009

On the other hand, as can be seen in Figure 2, the Mediterranean ship emissions appear important probably due to the more shipping (and ship emissions) along coastal routes frequented by containerships along coastal shipping, particularly in the Europe and Mediterranean areas.

\section{REGULATION}

The International Maritime Organization (IMO, 2009) commenced a debate on the reduction of emissions to air form ships in the 1980's. MARPOL's Annex VI was published in 1998 and came into force May 19, 2005, and was revised in 2008. The main changes were as follows:

Reduce the global cap on sulphur content in fuel oil to $3.50 \%$ (effective January 2012), then progressively down to $0.50 \%$ (effective January 2020)

Reduce limits applicable in Sulphur Emission Control Areas (SECAs) to $1.00 \%$ sulphur content (effective July 2010), being further reduced to 0.10\% (effective January 2015)

Reduce limits on nitrogen oxide (NOx) emissions from marine engines, with the most stringent controls on so-called "Tier III" engines (i.e., those installed on ships after January 2016) operating in Emission Control Areas.

Appendix III defines the criteria and procedures for designation of an Emission Control Area (ECA).
An ECA should be considered by adoption by the IMO is supported by a demonstrated need to prevent, reduce and control emissions of SOx, NOx and particulate matter (PM) from ships.

The proposal considering criteria for designation of an ECA shall include:

1 A clear delineation of the proposed area of application, along with a reference chart on which the areas is marked;

2 The type or types of emission(s) that is or are being proposed for control;

3 A description of the human populations and environmental areas at risk from the impacts of ship emissions

4 Emission quantification and impact assessment

5 Prevailing meteorological conditions

6 Data on marine traffic

7 Land based measures

8 The relative costs of reducing emissions from ships when compared with land-based controls and the economic impacts on shipping engaged in international trade.

Existing Emission Control Areas include:

- Baltic Sea (SOx, adopted: 1997 / entered into force: 2005)

- North Sea (SOx, 2005/2006)

- North American ECA, including most of US and Canadian EEZ (NOx \& SOx, 2010/2012).

- US Caribbean ECA, including Puerto Rico and the US Virgin Islands (NOx \& SOx, 2011/2014).

Experts expect proposals for other ECAs to be submitted to the Marine Environment Protection Committee (MEPC) in the near future. Most likely candidates are the coastal waters of Mexico and Japan. Norway is also expected to propose an ECA for its coastal waters in the Norwegian Sea, which would be the first ECA in Arctic waters. Proposals for ECAs in the Mediterranean Sea and Straits of Malacca are also expected; however, it will likely be years before it is feasible to meet ECA requirements in these highly trafficked areas.

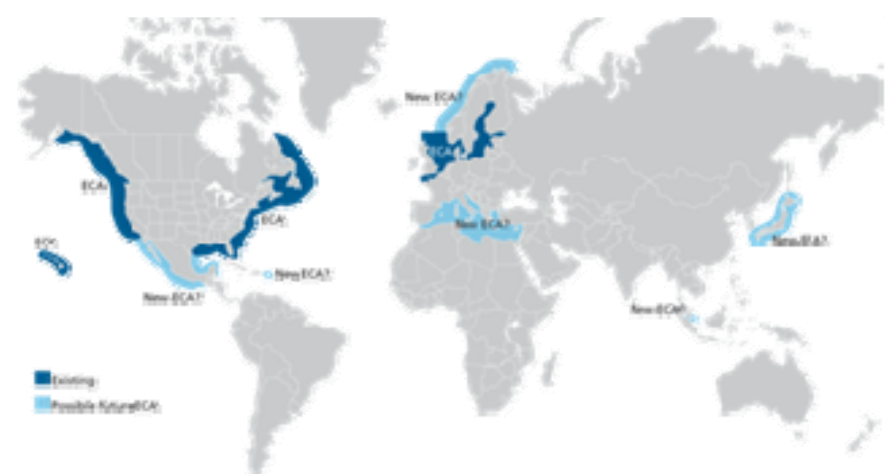

Figure 3. DNV's map of current and possible ECAs in the future. Source: Det Norske Veritas (DNV)

This paper will analyze relevant information pertaining to weather conditions to demonstrate how marine emissions will impact the sea and land ecology at risk in the Mediterranean. 


\section{METHODOLOGY}

To evaluate prevailing meteorological conditions criteria, relevant information pertaining to weather conditions and, particularly, wind patterns in the Mediterranean area is required to demonstrate how marine emissions will impact the sea and land ecology at risk.

Descriptions of climatic conditions which are found in aids to navigation (Pilots, Routing Charts, and Pilot's Charts) make use of average values of meteorological elements. Such an approach follows the methods applied in classical climatology where climate is treated as "a mean state of atmosphere in a many year period” (Fredynus, 2012). The frequency of occurrence of types of adverse or unfavourable weather conditions is extremely important for determinate marine emissions at land.

Predominately onshore winds result in greater pollution on land. Moreover, topographical, geological, oceanographically, morphological or any other conditions that could lead to increased probability of higher localized air pollution or levels of acidification. Mountainous regions inshore impacted by onshore winds can lead to intensification of air pollution and acid deposition. The situation in the Mediterranean is more complex with varied geography and more complex wind conditions that are more localized and seasonal.

This paper will focus on predominant wind pattern in the Mediterranean to demonstrate areas at risk. Detailed weather conditions are held by a number of organizations, for instance: www.puertos.es, www.idromare.it, www.eurometeo.com and Mediterranean Pilot Volumes of the Admiralty charts and publications.

\subsection{Mediterranean climate}

The Mediterranean climate use to be known due to its mild and wet winters and dry and hot summers. This climate even being very similar to the one of California, central Chile, South Africa or SW of Australia; is due to the topographic close of the sea basin.

We can define two main questions: First of all, in general terms, from October and during the winter season, the high pressure of Azores is reduced in extension and it affords the Atlantic lows to reach southernmost areas. In this season, the Northern Eurasia countries are cooled quickly, whilst the rest of the Mediterranean remains warmer. This means that the Polar and Arctic air masses in its advance to South, will suffer a very intense convection. This situation drives to a Ciclogenesis episode, mainly in the Gulf of Genoa, South of Ionian Sea and around Cyprus Island.

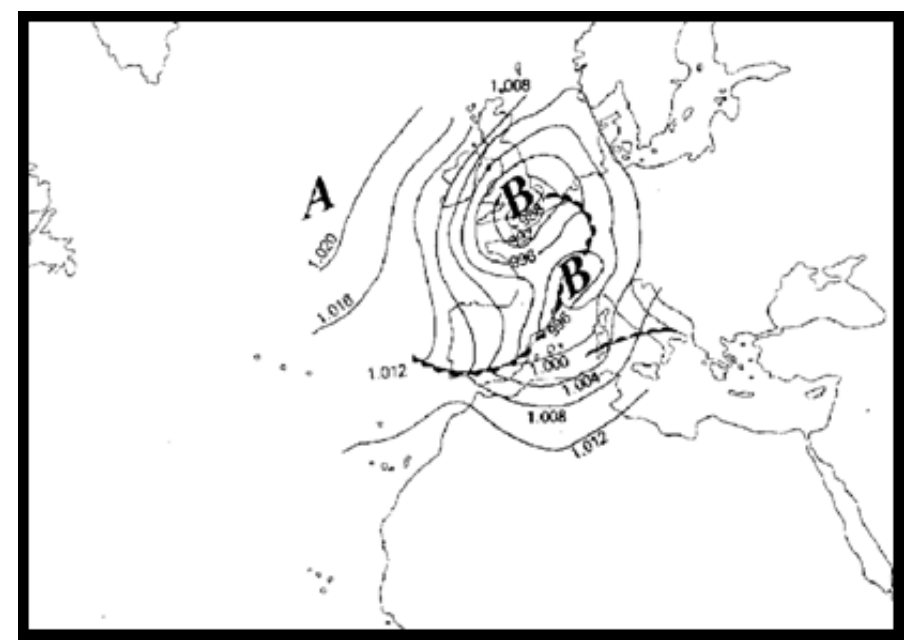

Figure 4. North situation in the Gulf of Genoa. Source: Sailing Directions Nr. 1 Costa Oriental de la Península Ibérica. Instituto Hidrogáfico de la Marina. Ministerio de Defensa. 1990.

On the other hand, to understand the Mediterranean climate, the local winds must be understood. Some of them have a synoptic effect like the Mistral, whilst some others are mainly local. The Mistral (NW), blowing down the Rhone valley, empties into the Gulf of Lion and usually appears with a pattern characterized by the position of a low pressure centred in the Balkans, close to the centre of the high pressure the Azores, together generating a pattern of situation of North winds in French territory. The topographic barriers will later address it as a North West.

During the winter, the wind effect is reinforced by the cooler snow coverage of that area, causing the downward flow of air from the Alps and the Massif Central (France) (see figure 4). The gravitational collapse of cold air and therefore, dense towards the bottom of the valleys, is called katabatic wind. Which is a dry wind, cold, down the valley of the Rhone, and when combined with a strong pattern of synoptic wind, can produce wind speeds of up to 8085 knots in the vicinity of the Rhone delta. Between December and May, occurs an average of 26 days during which the Mistral can blow at 33 knots or more, with a slight peak of activity between March and April (11 days between the two). These winds are falling rapidly when they penetrate into the sea, but occasionally can be extended to the island of Malta or North Africa. The danger for navigation is actually the rise in a short time: high seas. This phenomenon that occurs mainly in March, when the significant wave height in the southern part of the Gulf of Lion, reaches 2 meters, one of the highest among statisticians in the Mediterranean.

The same effects are associated with the katabatic Bora, which is a NE wind, which blows on the Eastern shore of the Adriatic Northern winter occurs where violent storms and gusts at times up to 100 knots. These conditions are intensified when the Mediterranean Low pressure is well developed and 
maintained a high pressure lingering over Europe. In particular behind a cold front moving southeast over the Adriatic effect, is reinforced by katabatic descent of cold air from the mountains Dalmatians. All these features well defined throughout the year, we find unexpected effects that do pose a greater hazard to navigation.

Along the Eastern coast of Spain, we find the East wind and gales, which are part of the change as well as the local winds during the winter half of the year. The first characteristic of these storms pattern $\mathrm{NE}$ and ENE, passing squalls associated with the Mediterranean between France and Algeria may cause seas really hard when the wind settles and finds considerable NE fetch, showed in figure 5 \& 6 .

These storms are more frequent and dangerous especially in autumn and spring. The storm characterized by strong winds from the SW, across the Strait of Gibraltar, up the Spanish coast depressions associated with advancing from the late fall to early spring. The main danger is triggered violent storms and electrical appliance involved. The transition from prevailing winds between the two halves of the year completely alters the character of the local winds. In the absence of ciclogenesis, local wind patterns are dominated by the following: where the wind comes from and what happens when it blows.

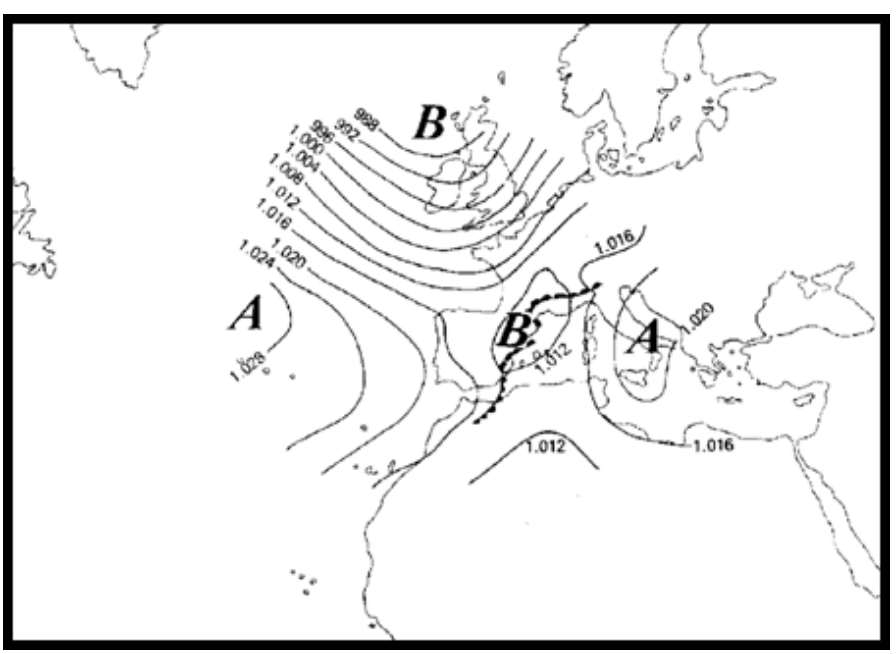

Figure 5. South situation in the Gulf of Genoa. Source: Sailing Directions Nr. 1 Costa Oriental de la Península Ibérica. Instituto Hidrogáfico de la Marina. Ministerio de Defensa. 1990.

For example, the Sirocco is the warm wind SW associated with the advance of a depression moving east direction across the Mediterranean (see figure 7), being most common in the spring because the subtropical high pressure moves north. Since it has warm, dry and full of dust from the Sahara, crossing the Mediterranean when it absorbs large amounts of moisture, makes it an unpleasantly warm and wet air. The most obvious consequence of the Khamsin is its emergence as almost spontaneously without previous evidence, of a narrow channel of wind posing a threat to coastal terminals with open basins, where large ships could be docked (big Bulk carriers, Tankers or Containerships). Due to that channel wind lifts. Another problem for navigation is when the air passes over the colder waters in the Northern Mediterranean in the spring or early fall, quickly forming a dense fog.

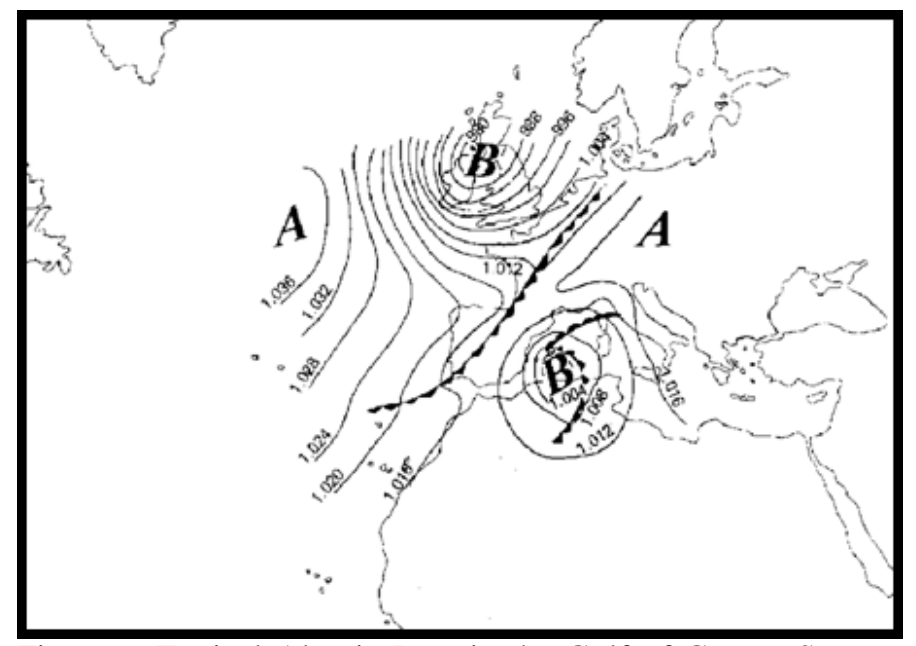

Figure 6. Typical Algeria Low in the Gulf of Genoa. Source: Sailing Directions Nr. 1 Costa Oriental de la Península Ibérica. Instituto Hidrogáfico de la Marina. Ministerio de Defensa. 1990

But perhaps the most famous summer winds are Etesian (the Meltemi Turkish) blowing from the NE and NW Aegean Sea. These are the consequence of a low pressure system extending from NW Anatolia to India, formed by the intense warn down suffered in the region. These winds reach maximum intensity during the month of August when hovering around 15 knots in the southern Aegean, resulting in variable weather conditions, which benefit the coastal regions moderating temperature. Occasionally they can be associated with violent storms, produce winds and sudden squalls (known as Bourini in Greece), causing considerable damage to local navigation.

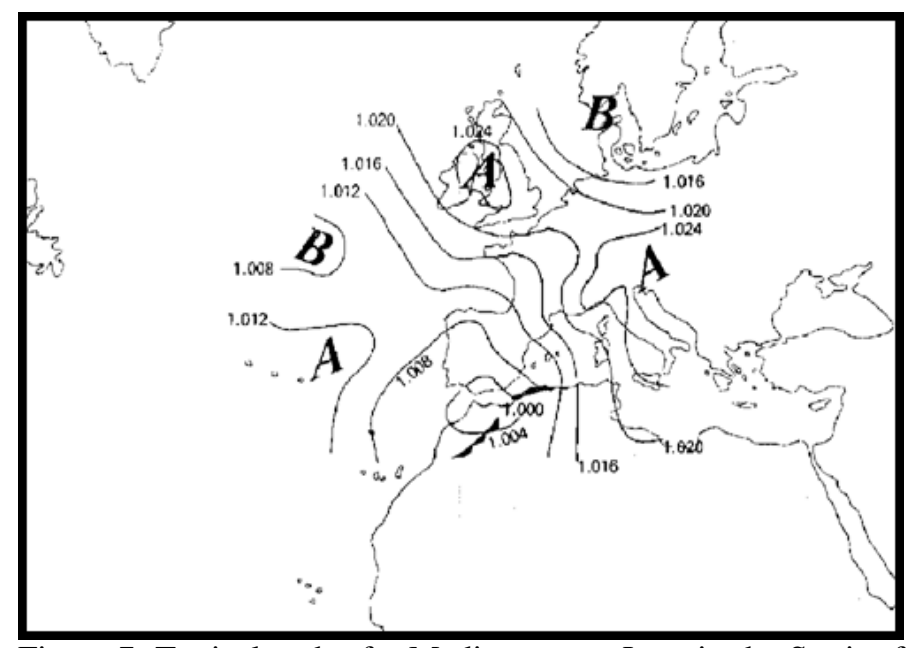

Figure 7. Typical path of a Mediterranean Low in the Strait of Gibraltar. Source: Sailing Directions Nr. 1 Costa Oriental de la Península Ibérica. Instituto Hidrogáfico de la Marina. Ministerio de Defensa. 1990. 


\section{CONCLUSIONS}

This paper has analyzed one of the parameters to evaluate the adoption of a future ECA in the Mediterranean Sea: the prevailing weather conditions.

Obtained analysis demonstrates that the weather pattern in the basin of the Mediterranean is affected by many differing systems and is quietly unpredictable being quick to change and often very different at two places only a short distance apart. Due to the high surrounding land masses and the latitude, the climate can at times be extreme but on the average it is very pleasant especially in the summer months. As big conclusions, we can confirm that excluding the coastal breezes that can carry the smoke among ten to twelve miles inside the shore when it blows from sea, the Mediterranean is characterized by strong Northerly winds in winter time within the Gulf of Lyon, Adriatic Sea and Aegean sea, that carry the smoke to the south coast of the basin. In the other hand, we can face opposite situations when lows travel across the Mediterranean, bringing the air masses from South to the European coasts, as the cases of Sirocco, Ghibli or Khamsin

Further research is needed to evaluate the rest of criteria to designate a future ECA in the Mediterranean Sea. The emission quantification and impact assessment and land based measures concurrent with the ECA adoption criteria has been evaluated in previous work (Usabiaga et al, 2012).

In this respect an ECA proposal by a Mediterranean country is all the more essential keeping in mind that since its proposal, around five years is needed until its adoption. On the contrary by 2017 road transport will have swept away maritime transport.

\section{REFERENCES}

[1] Admiralty Charts and Publications. Mediterranean Pilot. Volumes I to VI.
[2] Eiden G. et al, 2010. Performance of AIS sensors in space PASTA-MARE project final report executive summary

[3] European Commission, 1998. Directive 1998/70/EC of the European parliament and of the council. Official Journal of the European Union.

[4] European Commission, 2005. Directive 2005/33/EC of the European parliament and of the council. Official Journal of the European Union.

[5] European Commission, 2009. Directive 2009/30/EC of the European parliament and of the council. Official Journal of the European Union.

[6] European Union, 2011. EU transport in figures. Statistical pocketbook 2011. 22 p.

[7] Eurostat, 2012. Maritime transport statistics - short sea shipping of goods. Available from internet: $<$ http://epp.eurostat.ec.europa.eu/statistics_explained/index. php/Maritime_transport_statistics__short_sea_shipping_of_goods $>$.

[8] Ferdynus, J, 2012. Polish Seaports - Unfavorable Weather Conditions for Port Operation (Applying Methods of Complex Climatology for Data Formation to be Used by Seafaring). International Journal on Marine Navigation and Safety of Sea Transportation, Volume 6 Number, p 131139.

[9] International Maritime Organization (IMO), 2009. Revised MARPOL Annex VI - Regulations for the prevention of air pollution from ships and NOx Technical Code. London.

[10] Meech R., 2008. Designation of the Mediterranean Sea as a SOx Emission Control Area (SECA) under MARPOL Annex VI. SAFEMED project, task 3.7.

[11] Official Spanish ports portal. Available from internet: www.puertos.es

[12] Usabiga J.J, Martínez de Osés F.X., Castells M, 2012. ASSESSMENT FOR POSSIBLE FUTURE ECA ADOPTION IN THE MEDITERRANEAN AREA (Short Sea Shipping vs. Road Transport). International Conference on Traffic and Transport Engineering. Belgrade

[13] Wall C., 2007. Ships Emissions Inventory Mediterranean Sea. Entec UK limited.

[14] Website of general Mediterranean weather. Available from internet: www.eurometeo

[15] Website of Istitute Superiore per la Protezione e la Ricerca Ambientale. Available from internet: www.idromare.it

[16] Winebrake, J. J.; Corbett, J. J.; Green, E. H.; Lauer, A.; Eyring, V., 2009. Mitigating the Health Impacts of Pollution from International Shipping: An Assessment of Low-Sulfur Fuel Mandates. Environmental Science and Technology, 43(13), p.4776-4782.

[17] Xiang, Z et al, 2012. Applied Research of Route Similarity Analysis Based on Association Rules. International Journal on Marine Navigation and Safety of Sea Transportation, Volume 6 Number 2, p 181-185. 